\title{
Läbi raskuste tähtede poole: doktoritööde juhendajate kraadiõpingute kogemused ja nende seosed juhendamispraktikaga
}

\author{
Liina Lepp ${ }^{\text {a }}$, Marvi Remmik ${ }^{\text {a1 }}$, Äli Leijen ${ }^{\text {a }}$, Mari Karm ${ }^{\text {a }}$ \\ a Tartu Ülikooli haridusteaduste instituut
}

\begin{abstract}
Annotatsioon
Doktoriõppe eesmärkide mitmekesistumine ja muutused doktoriõppe korralduses on andnud ainestikku erinevateks uurimusteks. Juhendamispraktikat analüüsivate uurimuste keskmes on olnud juhendajate juhendamistegevused ja arusaamad doktoriõppe eesmärkidest. Üks juhendamispraktikat mõjutavaid tegureid on juhendajate kraadiõppe kogemus. Uurimuse eesmärk on kirjeldada Eestis tegutsevate juhendajate kujunemise tausta ning osutada võimalikele seostele nende kraadiõpingute kogemuste ja juhendamispraktika vahel. Andmeid koguti poolstruktureeritud intervjuuga 21-lt haridus- ja loodusteaduste valdkonna juhendajalt. Andmete analüüsimisel kasutati temaatilist analüüsi. Uurimuse tulemused osutasid, et juhendajad väärtustasid õpinguteaegset võimalust pühenduda väitekirja koostamisele, hoolivaid suhteid juhendaja ja juhendatava vahel ning toetava kogukonna olemasolu. Juhendamispraktikasse on üle võetud näiteks avatud suhtlusviis, toetava konstruktiivse tagasiside andmine, üliõpilase toetamine iseseisvaks uurijaks kujunemisel.
\end{abstract}

Võtmesõnad: kraadiõpe, aspirant, doktoriõpe, doktorant, juhendamine, intervjuu

\section{Sissejuhatus}

Viimastel aastakümnetel on doktoriõppe arendamisele ja tulemuslikumaks muutmisele pööratud olulist tähelepanu. Õppe katkestajate ja nominaalset õppeaega ületavate doktorantide suur arv (vt nt Kehm, 2004; Ots, Leijen, \& Pedaste, 2012; Vassil \& Solvak, 2012) on kinnitanud vajadust parandada

1 Haridusteaduste instituut, sotsiaal- ja haridusteaduskond, Tartu Ülikool, Salme 1a, 50103 Tartu; marvi.remmik@ut.ee 
doktoriõppe tulemuslikkust ja kvaliteeti ning suurendada erinevate osapoolte rahulolu. See omakorda on andnud ainest erineva rõhuasetusega uurimustele nii doktoritööde juhendajate, doktorantide kui ka laiemalt doktoriõpet kujundava hariduspoliitika valdkonnas. Kuigi doktoriõpet mõjutavaid tegureid on mitmeid, peetakse juhendamist üheks peamiseks õppe tulemuslikkust mõjutavaks näitajaks (vt nt Lee, 2008; Lovitts, 2001). Varasemates juhendamisteemalistes uurimustes on vaatluse all olnud nii juhendajaks saamine (Ives \& Rowley, 2005), juhendaja rollid ja juhendamistegevused (Barnes \& Austin, 2009; Kärner, 2008; Lee, 2008; Ots et al., 2012), juhendamisstiilid (Lee, 2008; Vilkinas, 2002), juhendamise õpetamine (Brew \& Peseta, 2004), juhendajate arusaamad teadustööst (Kiley \& Mullins, 2005; Lepp, Remmik, Karm, \& Leijen, 2013b) kui ka juhendamist mõjutavad institutsionaalsed ja hariduspoliitilised tegurid (nt Kehm, 2004).

Mitmes uurimuses tõdetakse, et isiklikud arusaamad juhendamise aspektide kohta kujundatakse varasema õppimis- ja teadustöö kogemuse põhjal (Barnes \& Austin, 2009; Delamont, Parry, \& Atkinson, 1998; Hemer, 2012; Lee, 2008; Stubb, Pyhältö, \& Lonka, 2011). Seetõttu leitaksegi, et üks juhendamise edukust mõjutavaid põhitegureid on see, kuidas juhendajat ennast juhendati. Samas on vähe empiirilisi uurimusi (nt Delamont et al., 1998), mille fookuses on küsimused „Kuidas on juhendajaid endid juhendatud?” ja „Kuidas varasem kogemus juhendatavana mõjutab praegust juhendamispraktikat?".

Siinses uurimuses käsitletakse eelnimetatud küsimusi Eesti kontekstis. Kuna paljud Eesti doktoritööde juhendajatest on olnud ise kraadiõppes poliitiliselt keerulisel ja muudatusterohkel ajal (sh üleminekul nõukogude režiimilt Eesti Vabariigile), on huvitav vaadelda eelneva kraadiõppe kogemuse seoseid tänapäevase juhendamispraktikaga. Järgnevalt tutvustatakse uurimuse teoreetilist raamistikku, mis kajastab juhendamist mõjutavaid tegureid kraadiõppe edukuse ja rahulolu mõjutajana.

\section{Teoreetiline raamistik}

Doktorikraadi omandamine on iga õppija jaoks ainulaadne ja isiklik kogemus, mis kujuneb erinevate tegurite koosmõjul. Varasemates uurimustes on esile tõstetud nii doktorandiga (nt Martinsuo \& Turkulainen, 2011; Ots et al., 2012) kui ka juhendaja juhendamistegevuste ja -stiiliga (nt Brew \& Peseta, 2004; Lee, 2008; Vilkinas, 2002) ning vastastikuste suhete ja kogukonna toetusega seonduvaid aspekte (nt Delamont et al., 1998; Martinsuo \& Turkulainen, 2011; Pyhältö, Stubb, \& Lonka, 2009). Järgnevalt tutvustatakse nimetatud kolme valdkonda põhjalikumalt. 


\section{Doktorant juhendatavana ja juhendaja roll doktorandi toetamisel}

Doktorandid erinevad nii teadmiste, oskuste, isiksusliku tausta kui ka perekondlike ja töökohustuste poolest (Eamets et al., 2014; Ots et al., 2012). Seetõttu on neil erinevad ootused ja vajadused juhendamise suhtes. Kam (1997) eristab doktorantide juhendamisega seotud ootuste ja vajaduste põhjal nelja juhendatava tüüpi: 1) sõltuvad juhendatavad, kes vajavad sagedasi ja pikki ning selgete juhistega arutelusid juhendajaga; 2) juhendatavad, kes vajavad juhendaja toetust peamiselt töö korraldamisel ja probleemide lahendamisel; 3) juhendatavad, kelle jaoks pole oluline juhendamiskohtumiste sagedus, vaid eelkõige konkreetne ja edasiviiv tagasiside juhendajalt; 4) juhendajast sõltumatud juhendatavad, kes saavad oma tööga enamasti ise hakkama, kuid väärtustavad siiski juhendaja hoolivat suhtumist ning sisulist tagasisidet. Martinsuo ja Turkulainen (2011) ning Kam (1997) jagavad arusaama, et kraadi omandamise protsessi määrab doktorandi ootuste ja omaduste ning juhendaja juhendamistegevuste ning arusaamade vastastikune mõju. Samas võib jääda juhendajapoolse toetuse täielik potentsiaal kasutamata, kui doktorant pole piisavalt pühendunud (Martinsuo \& Turkulainen, 2011). Seega on juhendamisprotsessis vajalik vastastikune ootuste jagamine ning nende kohandamine osaliste vajaduste ja eripäraga (Lee, 2008).

Erinevates uurimustes (nt Barnes \& Austin, 2009) on nimetatud mitmeid oskusi, mida juhendajatelt oodatakse. Juhendatavad peavad eduka juhendamise eelduseks juhendaja sügavaid teadmisi valdkonnast (Mainard, van der Rijst, van Tartwijk, \& Wubbels, 2009). Samas on Easterby-Smith, Thorpe ja Lowe (2002) seisukohal, et kitsast erialateadmisest on olulisemad juhendajate põhjalikud teadmised valdkonnale omasest uurimismetoodikast. Juhendaja peaks olema rahvusvaheliselt aktiivne uurija ja teadlaskogukonna liige ning toetama seeläbi ka juhendatava akadeemilist karjääri.

Juhendajal on tähtis osa eesmärkide püstitajana, arendavate ülesannete seadjana ning tagasiside andjana (Easterby-Smith et al., 2002). Brew ja Peseta (2004) leiavad, et juhendaja peab tundma huvi juhendamise vastu, omama juhendatava uurimuse ja juhendamisega seoses selgeid eesmärke ja ootusi, tagama, et kohtumised juhendatavaga oleksid produktiivsed ja regulaarsed, valdama mitmekülgseid juhendamisvõtteid ning analüüsima ja kriitiliselt hindama oma juhendamisoskusi.

Uurimustes, milles kirjeldatakse juhendamistegevusi juhendajate vaatenurgast, tuuakse esile juhendaja sarnaseid ülesandeid ja rolle. Näiteks eristavad Barnes ja Austin (2009) rolle, mis on seotud juhendaja tajutud kohustustega (nt toetada juhendatavat ja võimaldada tal kohaneda erialase kogukonnaga), juhendaja tegevustega (koostöö võrdväärsete partneritena, 
toetaja kogukonnas) ja juhendaja omadustega (sh sõbralikkus, hoolivus, ausus). Seega on tähtis, et hea juhendamine sisaldaks nii intellektuaalset kui ka afektiivset dimensiooni.

Sinclair (2004) teeb vahet osaleval (hands on) ja mitteosaleval (hands off) juhendamispraktikal. Osaleva juhendamise puhul teeb juhendaja juhendatavaga regulaarselt koostööd ning toetab seeläbi doktorandi edasijõudmist. Mitteosaleva juhendamise korral on kontakt juhendatavaga ja juhendajapoolne sekkumine minimaalne. Juhul kui juhendatava ootused ja vajadused on vastavuses juhendaja arusaamade ja tegevustega, on juhendatava rahulolu juhendamisega suurem kui juhtudel, kus juhendaja ja juhendatava ootustes on põhimõtteline vastuolu (Lee, 2008).

Peale osaleva ja mitteosaleva juhendamispraktika kirjelduste on uurimuste tulemusel loodud erinevaid mudeleid, mis iseloomustavad juhendajate arusaamu juhendamisest (vt Lepp, Karm, \& Remmik, 2013a). Üks enim rakendatud mudel pärineb Leelt (2008) ja see eristab viit juhendamisprotsessis enamasti omavahel põimunud juhendamisstiili: 1) funktsionaalne juhendamine, mida iseloomustab orienteeritus ülesannetele ning protsessi ja aja otstarbekas juhtimine; 2) kultuuri omandamine, mille puhul keskendutakse kogukonna käitumisreeglite omandamisele ja kogukonna liikmeks saamisele; 3) kriitiline mõtlemine, mille puhul väärtustatakse juhendatava analüütilist mõtlemist ja toetatakse selle suunas liikumist; 4) iseseisvumine, mille korral juhendaja peab oluliseks doktorandi isiksuslikku kasvu ja enesearengut; 5) suhete areng, mille puhul on kesksel kohal meeskonna loomine, hoolimine ja konfliktide juhtimise oskus. Lee (2008) leiab, et kuna juhendajate arusaamad ja hoiakud mõjutavad otsest juhendamistegevust, siis avaldavad need mõju ka juhendamispraktika tulemuslikkusele. Kuna doktorant areneb akadeemiliselt õpingute vältel, vajab ta doktoriõppe eri etappidel erinevat toetust, mistõttu on tähtis, et juhendaja kombineeriks juhendamisstiile. Sinclair (2004) ja Halse (2011) jagavad seisukohta, et juhendamisstiili kohandamine doktorandi akadeemilise arengu järgi võimaldab juhendataval kujuneda iseseisvaks uurijaks.

Kokkuvõtvalt saab öelda, et juhendajalt oodatakse juhendaja rolli edukaks täitmiseks teadmisi nii erialavaldkonnast kui ka valdkondlikust uurimismetoodikast, aktiivsust rahvusvahelise uurijana ja isiklikku huvi ning sellega seoses pühendumist juhendatava uurimisteemale. Tulemuslikuks koostööks on vaja jagada ootusi osaliste vahel ning kohandada neid vajaduste järgi. 


\section{Doktorandi ja juhendaja suhted}

Kuna suhteid juhendaja ja juhendatava vahel peetakse oluliseks teguriks, mis mõjutab doktorandi rahulolu kraadiõppega, siis on tähtis sel teemal põhjalikumalt peatuda. Kuigi Granti ja Grahami (1999) kohaselt on juhendamissuhtes nii juhendatav kui ka juhendaja aktiivsed suhete loojad, siis doktoriõppe kontekstis käsitletakse juhendajapoolset toetust enamasti selle põhjal, millisena doktorandid tajuvad oma suhteid juhendaja ja laiemalt akadeemilise kogukonnaga (vt nt Martinsuo \& Turkulainen, 2011; Phillips \& Pugh, 2000; Stubb et al., 2011). Suhted, mida doktorandid tajuvad positiivsena, soodustavad nende edukust ja õpingutes edasijõudmist, seevastu halvana tajutud suhted mõjuvad negatiivselt õpingute õigeaegsele lõpetamisele (Phillips \& Pugh, 2000). Lee (2008) järgi võivad juhendajad doktorandi „luua või hävitada”. Hockey (1994) peab doktoriõpingutes kõige kriitilisemaks esimest aastat, sest sel ajal kogetud intellektuaalsed ja sotsiaalsed protsessid on doktorandi jaoks uudsed ning võivad tekitada raskusi. Seetõttu on juhendajal suhete ülesehitamisel täita tähtis osa just kraadiõpingute algusperioodil. Phillips ja Pugh (2000) leiavad, et doktorandid peaksid juhendaja valikul mõtlema, kui lähedast töösuhet nad oma juhendajaga soovivad. Rõhutatakse (Wisker, 2001), et juhendamissuhte seisukohalt on olulised vastastikune austus ja akadeemiline usaldusväärsus.

Sambrook, Stewart ja Roberts (2008) ning Barnes ja Austin (2009) eristavad kolme liiki juhendamissuhteid: 1) distantseeritud akadeemiline juhendamissuhe, milles juhendaja ja juhendatav on omavahel küll sõbralikes suhetes, aga juhendaja ei osale doktorandiga juhendamisvälistes sotsiaalsetes tegevustes; 2) familiaarne akadeemiline juhendamissuhe, milles juhendaja ja juhendatava vahel domineerivad kollegiaalsed suhted (juhendaja püüab vähendada enda ja juhendatava vahelisi võimusuhteid, et juhendatav tunneks ennast võrdse partnerina); 3) familiaarne sotsiaalne juhendamissuhe, milles on akadeemilise ja sotsiaalse konteksti segunemise tõttu juhendaja ja juhendatava roll hägustunud, nt juhendaja pakub juhendatavale emotsionaalset ja psühholoogilist toetust, mis seisneb muu hulgas isikliku elu probleemide lahendamises.

Juhendamissuhted võivad mõjutada ka seda, kuidas juhendatavad tajuvad oma tööle antavat tagasisidet. Näiteks toovad Ives ja Rowley (2005) ning Wisker (2001) esile juhendaja ja juhendatava otsese sõbrasuhte ohud, mis võivad muuta tagasiside andmise keeruliseks. Lisaks on uurimused näidanud, et tagasisidestamisel on tähtis ka keskkond. Hemer (2012) on doktorantide hulgas korraldatud uuringu põhjal leidnud, et konstruktiivset kriitikat on juhendataval lihtsam vastu võtta mitteformaalses keskkonnas. 


\section{Kogukond doktorandi toetajana}

Doktoriõppe käigus peab doktorant omandama valdkonnale omased väärtused, suhtumise, normid ning teadmised ja oskused, mis on vajalikud teadlaste kogukonnas toimetulekuks (Gardner, 2010). Doktorantide jaoks on akadeemiline kogukond oluline õppimiskeskkond (Pyhältö et al., 2009). Doktorandi arengu toetamiseks on vaja kujundada keskkond, milles doktorandid tunnevad end kompetentsete, kogukonna jaoks oluliste uurijate ja väärtuslike liikmetena (Stubb et al., 2011). Lee (2008) ning Pole, Sprokkereef, Burgess ja Lakin (1997) peavad juhendajat tähtsaks lüliks suhete kujundamisel juhendatava ja erialase akadeemilise kogukonna vahel. Juhendajast sõltub suurel määral see, kuidas juhendatavad mõistavad oma eriala, rolli ning vastutusala akadeemiliste professionaalidena (Lovitts, 2001).

Uurimustes käsitletakse ka sotsialiseerumise ja ühistegevuste vajalikkust kraadiõpingutes. Näiteks leiavad Lovitts (2001) ja Gardner (2010), et doktorandi vähene või ebapiisav suhtlus kogukonnaga võib viia õpingute katkestamiseni. Stubbi jt (2011) uurimus näitab, et 56\% doktorantidest, kes olid tundnud vähest akadeemilise kogukonna toetust, pidasid seda oma õpingutes edasijõudmatuse üheks põhjuseks. Need, kes olid kogenud akadeemilise kogukonna toetust, tõid aga esile kuuluvustunde kui ühe teguri, mis pani neid kraadiõpingutes edasi pingutama.

Teadusvaldkonnad erinevad üksteisest selle poolest, millised on nende valdkondlikud sotsialiseerumis- ja koostöötavad (Golde, 2005). Loodusteadustes, kus doktorandid töötavad sageli samas laboris uurimisgrupina, on sotsialiseerumine lihtsam kui humanitaarteadustes, kus tihti ollakse oma uurimisteemaga üksi ja isolatsioonis (Gardner, 2009; Golde, 2005). Valdkondlikud traditsioonid kanduvad edasi ka juhendamissuhetesse. Nii on loodus- ja täppisteaduste doktorantidel sagedast suhtlust juhendajaga märksa enam kui humanitaarvaldkonna doktorantidel, samuti on neil rohkem võimalusi koostööks (nt ühisartiklid).

Lahenius (2012) on seisukohal, et koostöövõimaluste puudumisel võib jääda kogukonnas töötamise kogemus saamata, mistõttu tuleks leida selliseid võimalusi ka individuaalselt töötavatele doktorantidele. Ühe võimalusena nähakse siin praktikakogukonda (Lave \& Wenger, 1991), milles õpitakse üksteiselt kogemuste ja info jagamise kaudu ning seeläbi arenetakse nii personaalselt kui ka professionaalselt. Dysthe, Samara ja Westrheim (2006) soovitavad kraadiõppurite juhendamisel enam ära kasutada ka kaasõppijate potentsiaali, et kaasata kraadiõppur akadeemilisse kogukonda. Võimalike koostöövormidena pakuvad nad välja näiteks kollokviumi (colloquia), kus kraadiõppurid kohtuvad regulaarselt omavahel ning arutavad õpingute 
ja uurimustega seonduvat, või juhendamisrühmi (group supervision), kus juhendajad kohtuvad üksi või mitmekesi regulaarselt kraadiõppuritega ning arutavad toetavas õhkkonnas konkreetse uurimusega seotud küsimusi.

Juhendaja juhendamisarusaamad, juhendamisstiili kujunemine ning seejuures kogukonna rolli ja koostöötamisvõimaluste väärtustamine on Delamonti jt (1998) ja Lee (2008) järgi mõjutatud sellest, missugune on olnud juhendaja enda kraadiõppe kogemus. Uurides võrdlevalt juhendajate kraadiõppe kirjeldusi ja nende hilisemat juhendamispraktikat, on leitud, et kui oma õpingute ajal tunti puudust juhendaja hoolimisest ja tähelepanust, tajuti liigset ebamäärasust ning üksijäetust ja isoleeritust, siis hilisemas juhendamispraktikas püütakse oma doktorante toetada nii funktsionaalsema juhendamise kaudu kui ka kogukonda kuulumise võimaluste loomisel (vt lähemalt Delamont et al., 1998).

Teoreetilisi vaatenurki kokku võttes võib öelda, et juhendamisprotsessi edukust mõjutavad mitmed tegurid, millest doktorandiga seotu kõrval on olulised ka juhendaja ja kogukond. Autoritele teadaolevalt leidub vaid üksikuid empiirilisi uurimusi selle kohta, kuidas juhendajad tõlgendavad oma kraadiõpingute kogemusi ja nende mõju hilisemale juhendamispraktikale (vt nt Delamont et al., 1998; Lee, 2008). Samas on need uurimused näidanud, et juhendajate arusaamad juhendamise aspektidest on mõjutatud nende varasemast õppe- ja teadustöö kogemusest ning üldiselt kalduvad juhendajad oma õpinguaegadest meeldiva ja kasulikuna tajutud tegevusi hilisemas juhendamispraktikas kordama ning vastupidiseid tegevusi vältima. Artiklis püütakse avada praeguste juhendajate juhendatavaks olemise teemat Eesti näitel laiemalt. Seega on uurimuse eesmärk kirjeldada Eestis tegutsevate juhendajate kujunemise tausta ning osutada võimalikele seostele nende kraadiõpingute kogemuste ja juhendamispraktika vahel. Uurimuses otsiti vastuseid järgmistele uurimisküsimustele:

1) milliseid tegevusi ja sündmusi oma kraadiõpingute ajast peavad juhendajad oluliseks?

2) keda tuuakse oma kraadiõpingutest rääkides esile tähenduslike inimestena ja millised on nende rollid?

3) millised seosed on juhendajate arvates nende endi kraadiõpingute aegse juhendamise ja praeguse juhendamispraktika vahel? 


\section{Metoodika}

\section{Eesti kraadiõppe kontekst}

Tartu Riiklik Ülikool (olles omal ajal ainus Eestis asuv ülikool) sai 1945. aastal NSV Liidu I kategooria ülikooliks, millega kaasnes õigus võtta kaitsmisele väitekirju ja avada aspirantuur (Siilivask \& Palamets, 1982). Aspirantuuri kestus oli kolm aastat ning sinna õppima asumiseks tuli teha sisseastumiseksamid. Õpe aspirantuuris seisnes ainekursustel osalemises ja eksamite sooritamises ning teadustöö tegemises. Õppimiseks oli vaja eesti keele kõrval vallata ka vene keelt, sest kättesaadav teaduskirjandus oli venekeelne ja ka juhendajad olid toona sageli Venemaalt (vene keelt kõnelevad). Aspirantuuri lõpus õiendati komisjoni ees kandidaadi miinimumeksamid ning aspirantuuri lõpetamiseks tuli peale kandidaaditöö publitseerida ka kaks artiklit, millest vähemalt üks pidi olema avaldatud üleliidulises ajakirjas. Kandidaaditööd kaitsti komisjoni ees, mille koosseis kinnitati Moskvas (Saarniit, 2014). Erialadel, kus ülikoolil polnud väitekirjade kaitsmise nõukogusid, kaitsti väitekirju teiste Nõukogude Liidu ülikoolide ja teadusasutuste juures. Sobivate juhendajate puudumisel Eestis võidi aspirandile määrata ka juhendaja Venemaalt (Siilivask \& Palamets, 1982).

Pärast nõukogude aja lõppu ehk Eesti Vabariigi algaastatel (taasiseseisvumine aastal 1991) oli otsinguterohke aeg, kus tegeleti sobiva kraadiõppesüsteemi väljatöötamisega. Otsiti lahendusi, kuidas nõukogudeaegses aspirantuuris õpinguid alustanud saaksid Eesti Vabariigis doktorikraadi kaitsta (Saarniit, 2014). Ülikooliseadusega (1995) sätestati erinevate õppeastmete (sh doktoriõppe) nominaalse õppeaja, õppe alustamise ja lõpetamise tingimused. Koostati doktoriõppekavad, milles oli suurenenud aineõpingute osakaal, ning Saarniidu (2014) sõnul võeti üldine suund õppe suurema formaliseerituse poole.

Praegu toimub doktoriõpe ülikoolides õppekavade alusel ja kestab neli aastat. Õpingud on jagatud kohustuslikeks, valik- ja vabaaineteks. Õpingute kogumaht on 240 Euroopa ainepunkti (EAPd), millest aineõpingud moodustavad 60 EAPd. Doktoriõpe lõpeb doktoritöö kaitsmisega ja doktoriõppe edukalt lõpetanud isikule antakse teaduskraad - doktorikraad.

\section{Valimi iseloomustus}

Uuring põhines poolstruktureeritud intervjuudel 21 juhendajaga (11 meest, 10 naist; 15 haridusteadustest ja 6 loodusteadustest) kahest Eesti ülikoolist. Enamik osalejatest töötas professori või dotsendi ametikohal. Kümme uuritavat olid kraadiõpingud lõpetanud enne Eesti taasiseseisvumist 
(aspirantuuri ajal; lõpetamine aastatel 1970-1991), 11 juhendajat Eesti Vabariigi aastatel (4 juhendajat aastatel 1992-2000 ja 7 juhendajat aastatel 2000-2008). Anonüümsuse tagamiseks ei kirjeldata täpsemalt uuritavate valdkondi ega nimetata konkreetsemalt ópinguaastaid. Uuritavate taustandmed on esitatud tabelis 1 .

Tabel 1. Uuritavate kraadiõppega seotud taustandmed

\begin{tabular}{|c|c|c|}
\hline \multicolumn{3}{|c|}{ Lõpetamise aasta enne 1991. aastat $(n=10)$} \\
\hline $\begin{array}{l}\text { Juhendaja ja kaitsmine } \\
\text { NSV Liidu liiduvabariikides } \\
n=3\end{array}$ & $\begin{array}{l}\text { Juhendaja Eestis ja kaitsmine } \\
\text { NSV Liidu liiduvabariikides } \\
n=3\end{array}$ & $\begin{array}{l}\text { Juhendaja Eestis ja } \\
\text { kaitsmine Eestis } \\
n=4\end{array}$ \\
\hline \multicolumn{3}{|c|}{ Lõpetamise aasta peale 1991. aastat $(n=11)$} \\
\hline $\begin{array}{l}\text { Juhendaja Eestis ja kaits- } \\
\text { mine Eestis } \\
n=7\end{array}$ & $\begin{array}{l}\text { Juhendaja lääneriigis ja } \\
\text { kaitsmine Eestis } \\
n=2\end{array}$ & $\begin{array}{l}\text { Juhendaja ja kaitsmine } \\
\text { lääneriigis } \\
n=2\end{array}$ \\
\hline
\end{tabular}

Doktorikraadi kaitsmiseni jõudnud juhendatavaid ei olnud uurimuse andmekogumise ajal 6 juhendajal (praegune juhendatavate arv min 2 ja max 6, kokku juhendamisel 25 doktoranti). 1-5 kraadi kaitsnud lõpetajat oli 11 juhendajal ( $\min 1, \max 9$, kokku 45), 6 ja rohkem kraadi kaitsnud lõpetajat 4 juhendajal ( $\min 2$, max 6, kokku 18). Arvud põhinevad Eesti Teadusinfosüsteemi ja intervjueeritavate andmetel intervjuude toimumise seisuga.

\section{Andmekogumine}

See uurimus on osa laiemast uurimusest, mille eesmärk on kirjeldada ja analüüsida Eesti doktoriõppe juhendajate juhendamisarusaamu ja -praktikat (vt Lepp et al., 2013a; Lepp et al., 2013b). Andmete kogumiseks tehti aastatel 2011-2013 poolstruktureeritud intervjuud doktoriõppe juhendajatega kahest Eesti ülikoolist. Intervjuud olid 70-115 minuti pikkused (tüüpiliselt ca 90 minutit).

Uurimisküsimuste alusel koostati varasematele uurimustele (nt Lee, 2008; Sinclair, 2004) toetudes intervjuuküsimused. Peale esialgse kava koostamist (intervjuu kava valmis nelja uurija ühistööna) paluti hinnangut ja soovitusi sama valdkonna uurijatelt. Intervjuu kava täiendamise ja täpsustamise järel katsetati seda ühe juhendajaga. Olulisi muudatusi prooviintervjuu põhjal intervjuu kavas ei tehtud.

Intervjuu viimases osas, mille tulemustel artikkel põhineb, keskenduti juhendajate kraadiõppe kogemusele ja selle seostele praeguse juhendamisega. Intervjuu osa (pikema intervjuu viimast osa doktoriõppe juhendajate 
juhendamisarusaamade ja -praktika teemal) alustati üldise küsimusega Rääkige, kuidas Teid ennast juhendati?, millele järgnesid küsimused intervjuu kava järgi (vt lisa 1) ning täiendavad või täpsustavad küsimused vastavalt intervjuusituatsioonile ja vajadusele (nt Kas saaksite seda täpsustada?). Juhendajaid intervjueerisid individuaalselt neli uurijat.

Kõik intervjuud transkribeeriti täielikult (transkriptsiooni keskmiselt 22 lehekülge intervjuu kohta, transkribeeritud teksti kokku 453 lehekülge). Uuritavate identiteedi kaitsmiseks anti juhendajatele ja intervjuudes mainitud inimestele pseudonüümid.

\section{Andmeanalüïs}

Andmeid analüüsiti kvalitatiivse temaatilise analüüsi meetodil (Ryan \& Bernard, 2003). Esimese etapina identifitseeriti avatud kodeerimise kaudu esialgsed teemad (nt kraadiõpingute kontekst, mida kirjeldati kraadiõpingute aja puhul olulise tegurina, kirjeldused endast kraadiõppurina, suhe juhendajaga, juhendaja rollid ja tegevused, kogukond ópingute ajal, varasema ja praeguse juhendamise sarnasused ja erinevused). Teises etapis jaotati täpsustatud teemad ja alateemad sisulise sarnasuse alusel laiemate teemade alla. Viimases etapis kodeeriti kogu andmehulk eristatud teemade ja alateemade põhjal uuesti. Tulemuste usaldusväärsuse suurendamiseks identifitseerisid kaks autorit teemad paralleelselt ja jaotasid need laiemate kategooriate alla. Teemade ja alateemade jaotus arutati seejärel läbi artikli kaasautoritega. Kui teemade identifitseerimisel esines erinevusi, mindi tagasi algandmete juurde ja arutati otsuseid kuni konsensuse saavutamiseni. Analüüsi käigus koostati võrdlustabel, et kõrvutada erinevate intervjuude analüüsi tulemusi.

Uurimisküsimuste alusel jaotati uuringus osalejate kraadiõpingute kirjeldused temaatilise andmeanalüüsi käigus kolme laiema teemade ringi alla: 1) kraadiõppur õpingute ja väitekirja koostamise protsessis; 2) olulised inimesed kraadiõppe ja väitekirja koostamise protsessis; 3) seosed uuritavate kraadiõpingute kogemuse ja praeguse juhendamispraktika vahel.

Järgnevalt esitatakse tulemused teemade kaupa, kirjeldades alateemasid ja esitades tekstinäiteid tulemuste ilmestamiseks. Artiklis tsiteeritud intervjuukatkeid on parema mõistetavuse huvides vähesel määral toimetatud, vähendades täitesõnade hulka ja kordusi. 


\section{Tulemused}

\section{Kraadiõppur õpingute ja väitekirja koostamise protsessis}

Intervjuudes tõid juhendajad esile õpingutele pühendumist ja oskuslikku ajaplaneerimist ning enda iseseisvust ja töötahet. Need tegurid olid uuritavate kirjelduste järgi olulised, sest aitasid neil edukalt kraadiõppe lõpetamiseni jõuda.

\section{Kraadiõppuri pühendumine õpingutele ja planeerimisoskused}

Aspirantuuri ajal õppinud uuritavad meenutasid kraadiõpet ajana, mil pühenduti täielikult õpingutele. Aspirantidele makstav stipendium tagas majandusliku toimetuleku ning muud tasustatud tööd kraadiõppe ajal enamasti ei tehtud.

Nõukogude ajal inimene ei tohtinud töötada kahe või kolme koha peal, ühe koha peal võis ainult töötada. /.../ Mina olin aspirant, ma sain 100 rubla stippi, keskmine palk vabariigis oli 70 rubla. See oli nõukogude aja aspirant. (Jüri)

Olenemata sellest, kas õpiti aspirantuuris või doktorantuuris, kirjeldasid loodusteaduste valdkonna uuritavad õpinguid pideva tööna laboris, kus uurimisteema ja igapäevane töö olid tihedalt seotud ning seetõttu võidi väitekirjaga seonduvale pühenduda.

Doktorantuuri alguses ma olin 7 päeva nädalas, 365 [päeva aastas] praktiliselt ainult istusin tööl. Ma naeran, et see on see vaba mehe elu, et see oli minu vaba valik teha kõvasti tööd. (Ats)

Seevastu doktoriõppes õppinud haridusvaldkonna uuritavad kirjeldasid õpinguid enamasti muu tööga paralleelselt toimunud tegevusena. Üksikutel juhtudel oli doktorantide uurimisteema ja igapäevane töö osaliselt seotud, nt teadurina töötades saadi töö käigus teha ka oma doktoritööd. Enamik aga meenutas doktoritöö kirjutamist kui põhitööga otseselt mitte seotud tegevust, kus sageli põhitöö pigem takistas kui toetas väitekirja valmimist. Põhitööna töötati peamiselt ülikoolis lektori või spetsialistina või mõnes teadusasutuses, seega oldi akadeemilise kogukonna liige. Töötamist õpingute kõrvalt peeti vajalikuks eeskätt selleks, et majanduslikult toime tulla.

Kuna ma ju töötasin lektorina, siis ma pidin tegema õppetööd /.../, aga et need loengud oleksid kuidagi toetanud minu doktoritöö 
valmimist, et pigem see oli ikkagi segav faktor /.../. Et seda töökohta oli materiaalsetel põhjustel vaja, aga kõrvalt töötamine ikka pigem segas ja seetõttu ta ka venis ja venis ja venis. (Maie)

Kraadiõpet meenutades mainisid uuritavad õpingutes edasiliikumiseks vajaliku oskusena head planeerimisoskust, mida pidasid oluliseks nii need uuritavad, kes said õpingutele täielikult pühenduda, kui ka need, kes õppisid kraadiõppes põhitöö kõrvalt. Näiteks selgitati intervjuudes, kuidas väitekirja valmimise nimel töötati välja täpne tegevusplaan, mida järgiti ning mille täitmise järel premeeriti end vaba aja või muu meelepärase tegevusega. Planeerimisoskuste keerukust meenutasid enam naissoost uuritavad, kelle peres kasvasid õpingute ajal väikesed lapsed.

Ma jagasin oma aja niimoodi, et mul oli ka lapsehoidja teatud tunnid, ja siis ma tulin raamatukokku. /.../ Ma mõtlesin, et ma pean kirjutama, no ütleme nädalas 20 lehekülge ja siis ju kirjutati käsitsi. Kui see peatükk sai valmis, vot siis oli lust ja lillepidu vähemalt nädal. (Anu)

Tulemused osutasid, et olenemata kraadiõppe ajast toodi positiivsena intervjuudes esile väitekirja teema ja kraadiõppuri igapäevaste töökohustuste omavaheline seotus. Lisaks peeti oluliseks kraadiõppuri suutlikkust püstitada eesmärke ja nende nimel tegutsemist.

\section{Iseseisvus väitekirja koostamisel}

Kraadiõppe edukaks läbimiseks pidasid uuritavad tähtsaks suutlikkust iseseisvalt töötada. Iseseisvalt töötamine oli juhendajate kirjelduste kohaselt osale uuritavatest vaba valik ja sellesse suhtuti positiivselt. Leiti, et vähene kontakt juhendajaga ja iseseisvus otsustamisel on vajalik ja selline tööviis toetas väitekirja koostamist. Teisele osale uuritavatest oli aga iseseisev töötamine väitekirjaga ja vähene koostöö juhendajaga olude sunnil tekkinud olukord (nt kui juhendaja asus kaugel või juhendamine oli juhendatava jaoks ebapiisav), mistõttu oldi ebakindlad nii töö fookustamisel kui ka hilisemas töö kirjutamise etapis. Seega tõlgendati üksi töötamise ja iseseisvuse kogemusi erinevalt.

Uuritavad, kes õppisid aspirantuuris ja kelle juhendajad asusid Eestist väljas, kirjeldasid õpinguid peamiselt iseseisva tööna väitekirjaga ning arutelud juhendajaga toimusid üksikutel kordadel. Kuna kohtumised juhendajaga olid vahemaast tingituna harvad, siis valmistuti nendeks põhjalikult (nt kirjutati Eestis valmis väitekirja osa või artikli mustand ja sõideti seda 
juhendajale näitama). Enamasti peeti ennast sellistel juhtudel iseseisvaks, juhendajast sõltumatuks ja motiveeritud õppijaks.

Nägin teda [juhendajat] siis, kui ta oli nõus [aspiranti juhendatavaks võtma], ja nägin siis, kui autoreferaat [autori enda koostatud kokkuvõte oma uurimusest] oli valmis, aga mul ei olnud sellest sugugi puudust. Kirjavahetus juhendajaga oli ainult siis, kui mul oli autoreferaat juba valmis. (Anu)

Nii aspirantuuri kui ka doktoriõppe ajal õppinud haridusvaldkonna uuritavad kirjeldasid väitekirja koostamist iseseisva tööna, kus juhendaja poole pöörduti siis, kui juhendataval tekkis selleks enda hinnangul vajadus. Ka loodusteaduste valdkonna uuritavad kirjeldasid end töötahtelise ja iseseisvana, kuid sealjuures rõhutati enam juhendaja ja uurimisrühma toetust ning spontaanseid aruteluvõimalusi töörühmas.

Iseseisvat uurimist ja selle käigus eksimist peeti väärtuslikuks ning oluliseks kogemuseks. Ka siis, kui tööd kirjutades tunti end juhendajapoolse piisava toetuseta ja mõnikord tajuti iseseisvusega kaasnevat ebakindlust, meenutati uhkusega nii õpingute kui ka väitekirjaga edukalt hakkama saamist.

Mul lasti teha seda, mis ma tahtsin, ja siis, kui ma sain talle selle valmis töö lauale panna ja öelda, vot siin see on [juhendatav uhkusega]. (Pille)

Uuritavate töötahe avaldus intervjuudes ka selles, et otsiti pidevalt lahendusi piiratud vahenditest tingitud keerukatele olukordadele. Vahendite piiratusega seoses meenusid nõukogudeaegsetele juhendatavatele olukorrad, kus oli puudus teaduskirjandusest, tehnilistest või katsevahenditest. Ehkki olukordi kirjeldati teadustööd piiravana, oldi lahenduste otsimisel leidlikud ning töövahendite nappus ei saanud kandidaaditöö valmimisel takistuseks.

Kurat, aeg oli raske, mitte midagi teha ei saanud selles mõttes, et unistused olid suured, aga analüütilised võimalused olid ikka piiratud. Istusime ühe masina küljes kinni, pigistasime andmetest välja kõik, mis kätte andis saada. (Ats)

Meil ei olnud kirjandust. Endine aspirant oli siis välismaal ja tema sai ligi kirjandusele ja vaatas, mis maailmas toimus. Saatis meile iga päev ühe kollase ümbriku, nihukese paksu. Ta saatis no ikka tuhandeid lehekülgi sealt koopiaid kirjandusest. (Karl) 
Kokkuvõtvalt saab öelda, et olenemata sellest, kas õpinguteaegne iseseisvus oli kraadiõppuri vaba valik või olude sunnil tekkinud olukord, käsitleti seda tagasivaatavalt väärtusliku kogemusena iseseisvaks uurijaks kujunemisel. Kraadiõpinguid meenutades tunti uhkust, et oldi motiveeritud ja töötahtelised, mistõttu suudeti iseseisvalt töötada ning keerukatele olukordadele lahendused leida.

\section{Olulised inimesed kraadiõppe ja väitekirja koostamise protsessis}

Oluliste inimestena kraadiõppes ja väitekirja koostamise protsessis tõid uuritavad intervjuudes esile juhendaja, kaasõppijad, kogukonna ning perekonna. Juhendaja puhul tähtsustati nii tema üldist toetavat hoiakut kui ka tema rolli doktoriõppe protsessist läbijuhtijana. Kaasõppijad, kogukond ja pereliikmed olid tähtsad moraalse toetuse pakkujana, aga ka väitekirjaga seonduvates sisulistes aruteludes.

\section{Juhendaja olulise inimesena}

Kraadiõppe ja väitekirja koostamise protsessis kirjeldati olulise inimesena juhendajat. Mitmetel uurimuses osalenutel oli juhendajaga koostöökogemus eelmisest õppeastmest. See oli omakorda ajendiks, miks juhendaja oli teinud uuritavatele ettepaneku astuda kraadiõppesse. Selliseid juhtumeid kirjeldati kui tunnustust, et neid oli lootustandva üliõpilasena märgatud, ning juhendamissuhet meenutati peamiselt positiivse ja kraadiópinguid toetava kogemusena.

Minu n-ö korjas juhendaja näiteks praktikumist välja, sest ma hakkasin küsimusi küsima ja uurisin seal ikka rohkem kui teised, sest mind huvitaski see asi. Siis ta kutsus, et lähme teeme. (Karl)

Uuritavate hulgas oli ka neid, kes kirjeldasid varasemat juhendaja-juhendatava suhet õppimist takistavana. Varasema õppeastme õpilase-õpetaja juhendamissuhe jätkus ka kraadiõppes ning see, et juhendatav ei tundnud end juhendaja jaoks võrdse partnerina, takistas akadeemilist dialoogi. Uuritavad tunnistasid, et juhendatavana puudus neil julgus küsida küsimusi ja nõuda sisukamat juhendamist. Samuti oli varasema koostöösuhte tõttu keeruline vastanduda juhendaja arvamusele. Samas oli ka neid, kes julgesid selgelt juhendajast erinevale seisukohale jääda.

Minu juhendaja ütles mulle, olen oma juhendajaga olnud bakast alates, et bakas me ei vaielnud, magistris sa vaidlesid ja doktorantuuris sa vaidled kogu aeg vastu, nii kui ma midagi ütlesin, sa ütlesid kohe „ei”. (Pille) 
Seega võib uuringus osalenute intervjuude põhjal öelda, et kraadiõppuri varasemat koostöökogemust juhendajaga tajusid uuritavad nii edasist juhendamiskoostööd toetavana kui ka juhendamisprotsessi takistavana. Uuritavate kirjelduse põhjal ei olenenud koostöö üksnes juhendajast, vaid tähtis oli ka juhendatava julgus dialoogi alustada ja oma seisukohti põhjendada.

Juhendaja kraadiõppe protsessist läbijuhtijana. Intervjuudes meenusid uuritavatele erinevad tegevused, mille kaudu toetas juhendaja nende edasijõudmist õpingutes. Juhendaja rolli meenutati seoses uurimuse erinevate etappidega.

Kraadiõppe algusajast meenusid uuritavatele olukorrad, kus juhendaja soovitas asjakohast teaduskirjandust ja toetas uurimuse fookuse kindlaksmääramisel. Samuti oldi juhendajatele tänulikud selle eest, et nad kaasasid neid erinevatesse uurimisprojektidesse ja andsid juhiseid sobiva metoodika väljatöötamisel. Tavapäraseid juhendamissituatsioone meenutati peamiselt aruteludena, mis toimusid uuritavate sõnul enamasti nende endi initsiatiivil. Oluliseks peeti võimalust juhendaja poole pöörduda õppijale sobival ajal. Sellised juhendatava enda initsiatiivil toimunud kohtumised olid uuritavate kirjelduste põhjal omased nii nõukogude ajal kui ka hiljem õppinutele. Juhendamiskohtumistel andis juhendatav ülevaate töö hetkeseisust ja edasistest plaanidest.

Sai arutatud, mida ja kuidas teha, ja noh ütleme kui mingi artikkel sai kirjutatud, siis sai seda arutatud ja mõeldud, et kas nii või teisiti ja millistele konverentsidele minna. (Peep)

Loodusteaduste valdkonna uuritavad erinesid haridusvaldkonna uuritavatest selle poolest, et töötades koos juhendajaga uurimisrühmas, oli neil võimalus sagedasteks aruteludeks, mis omakorda toetas väitekirja valmimise protsessi.

Noh me suhtlesime nagu, ütleme nagu ... iga päev toimus juhendamine, kogu aeg tegime ka ikkagi koos tööd. (Karl)

Ka siis, kui juhendaja oli väljastpoolt Eestit, kirjeldati harva toimunud kohtumisi enamasti sisukate ja edasiviivatena, sest tunti, et nii kraadiõppur ise kui ka juhendaja olid kohtumisteks valmistunud ja keskendusid piiratud aja tõttu (uuritavad olid juhendajate juures vaid mõned päevad kuni nädalad) väitekirja edasiarendamisele, tehes intensiivselt ja pühendunult tööd.

Vajaliku ja väärtuslikuna nimetati intervjuudes ka kirjaliku tagasiside saamist juhendajalt. Näiteks kirjeldati olukordi, kus juhendaja tagasisidestas 
väitekirja suuremaid osi, andis nõu juba valminud artikli käsikirja kohta, nõustas väitekirja osade tervikuks sidumisel või kommenteeris autoreferaadi mustandit. Ka siis, kui esialgu tajuti tagasisidet motivatsiooni vähendavana ja emotsionaalselt kurnavana, oli uuritavatele tähtis, et juhendaja leidis aega põhjalikuks süvenemiseks ja sisukaks tagasisidestamiseks.

Ma saatsin talle [juhendajale] kirja ja ta kirjutas mulle, et see [autoreferaat] ei kõlba mitte kuskile. Ma mäletan, ma olen kuskile üles kirjutanud, et „must päev minu elus”. Mäletan, et ma kohutavalt nutsin. Täitsa õudus, see ei kõlba veel mitte kuskile. Siis ma läksin sinna raamatukokku ja leidsin sealt, mida panna sinna, ja polnudki midagi palju vaja. (Anu)

Juhendaja tegevuste kirjeldamisel peeti väärtuslikuks juhendaja kogemust kraadiõppe tervikprotsessi tajumisel. Kirjeldati juhendaja panust oponentide leidmisel ning kaitsmise protseduuriliste nõuannete esitamisel.

Tema muidugi tundis hästi seda protseduuri. Ütleme, et selle asja sisu tuli nagu minu poolt ja kogu vormiline ja protseduuriline tuli tema poolt ja see lõppes kaitsmisega. Subjektiivselt mul oli väga meeldiv. Ma teadsin, et mul on juhendaja ja kui mingi asi on, ma saan tema käest küsida. (Tõnu)

Samuti tähtsustasid mitmed aspirantuuri ajal õppinud juhendaja osa ajale omaste nõukogudeaegsete ideoloogiliste nõudmistega arvestamisel. Kuna kandidaaditöö pidi sisaldama nõukogude propagandat või sobituma nõukogudeaegsete seisukohtadega, siis suuniseid selleks saadi just juhendajalt.

Punased loosungid oli vaja ka veel sellel ajal sisse panna. Ümbruskond oli selline, et kui ikka viisnurka ei olnud löödud, otsiti mõned laused sinna. (Elmar)

Uuritavate hulgas oli ka neid, kes tundsid õpingute ajal puudust nii juhendaja toetusest töö fookustamisel kui ka laiemalt kraadiõppuri üldise arengu toetamisel. Kirjeldati, kuidas juhendajalt ei saadud õpingute käigus piisavalt tagasisidet, mis omakorda tekitas ebakindlust ja segadust. Samuti öeldi, et esines olukordi, kus tagasisidet tuli kaua oodata, ning see takistas töö edenemist.

Me ei käinud koos juhendajaga konverentsidel, ta ei suunanud mind lugemisperioodil, teoreetilise konteksti otsimise perioodil ega andmete 
kogumise ja analüüsi etapis. Tol ajal ma tundsin sellest suurt puudust ning tõenäoliselt kulutasin üleliia palju aega ekslemisele. Samuti on mul kahju, et ta ei suunanud mind kirjutama ja avaldama. /.../ No üks suvi ma olin nagu eriti vihane oma juhendaja peale, kus ma enda arvates saatsin talle juba suuri tükke. See suvine istumine ilma tagasisideta ning ilma igasuguse märgita, et kas ta on kätte saanud või midagi, oli üsna painajalik. (Alma)

Tulemused osutavad, et kraadiõppuri hinnangul ebapiisavat juhendamist tajuti õpinguaega meenutades emotsionaalselt kurnavana. Kuigi uuritavad väärtustasid iseseisvust, peeti oluliseks siiski juhendaja süvenemist õppuri töödesse ning julgustavat suunamist väitekirja koostamisel.

Juhendaja üldine toetav hoiak ja suhted juhendajaga. Juhendajaid meenutades väljendati heameelt selle üle, et suhted juhendajaga olid avatud ja pakkusid kraadiõppurile tuge. Juhendajat kirjeldati sõbraliku suhtlejana, väärtuslikuks peeti suhtlust võrdsel tasandil ning professionaalse suhtluse kõrval ka kolleegi- või sõbrasuhteid.

Ma õudselt hindan seda vaba akadeemilist dialoogi ja hindan seda, et mulle keegi ei ütle, et sa oled loll. Ühesõnaga doktoritöö kokkupanemisel oli ikka väga tore akadeemiline dialoog. Seda ma hindan väga. (Lydia)

Meeldejäävana kirjeldati intervjuudes olukordi, kus kraadiõppe keerulistel hetkedel saadi tuge juhendajalt, kes väljendas rahulolu juhendatava tööga ja usku uurimisteema väärtuslikkusse ning toetas seeläbi töö edasiarendamist ja valmimist.

Ma iga kord imestasin, et kuidas tema suudab nii vaimustuses minu tööst olla, ta oli palju rohkem sihuke motiveeritud ja vaimustuses. Ma ütlekski, et see juhendamise tugi tihtipeale, see emotsionaalne tugi, et see oli hästi oluline. See, et kui sul endal tekib see auk, et kõik on juba öeldud, et kõik on nii nõme ja jama ja midagi, et siis teed „oo” ja juhendaja toetab. (Kati)

Vaid ühel juhul (kui juhendajat vahetati) kirjeldati konflikti juhendajaga kraadiõppe algusperioodist, kus juhendaja ja juhendatava arusaamad uurimusest ei sobinud. 
Ma sain varsti aru, et juhendaja ja minu teed lähevad lahku. Seda teed, mida oli juhendaja valinud oma töödes ja uurimustes, mina ei saanud pidada perspektiivikaks. (Elmar)

Formaalsete juhendamissuhete kõrval kirjeldati intervjuudes ka mitteformaalses keskkonnas toimunud juhendamist. Selliste kogemuste puhul toodi esile võrdsustunnet ja väärtustati uurimistöövälist sotsiaalset suhtlust.

Ma olin päev otsa lugenud midagi ja tekkis mingi idee ja lähen siis õhtupoole tema juurde, tema ehitab maja. Noh ta ütleb mulle, et vaata, siin on kivihunnik, silikaadid, et need on vaja ülesse teisele korrusele visata. No siis ma võtsin ja loopisin need kivid ülesse teisele korrusele. Tema üleval püüdis ja pani riita. Kell oli kümme või pool üksteist, kui me lõpetasime, ja siis me läksime tema koju. /.../ Siis me hakkasime arutama teadust üks kaheteistkümneni või poole üheni. Aga see oli ühetoaline korter, kus me seda arutasime. Tema abikaasa oli sel ajal köögis. Nii käis teaduse tegemine. (Jüri)

Inimlikke (sh mitteformaalseid) suhteid väärtustati ka juhtudel, kui juhendamiskohtumisi ei tajutud kraadiõppes edasiliikumist toetavana. Nii aspirantuuri kui ka doktoriõppe aegadest meenutati värvikaid lugusid, kus hea ja inimlikul pinnal kontakt juhendajaga oli küll olemas, kuid see ei toetanud töös edasiliikumist.

Oli tore inimene, hea sõber, aga juhendajana väga tagasihoidlik. Sisulist abi ma ei saanud temalt peaaegu kunagi. (Tiiu)

Suhteliselt vara tehti selgeks see, et kui mina läksin Moskvasse midagi näitama või rääkima, et siis tuli võtta pudel valget viina ühes ja siis juhendamine ... siis algul natukene rääkisime tööst ja siis pandi see valge viin laua peale ja joodi kahekesi ära ja iga nihukene vestlus oligi siis noh umbes sellises formaadis ja lõpus läks siis hästi lõbusaks ja ütleme, ega sealt mitte liiga palju juhendamist ei tulnud. (Robert)

\section{Kaasõppijate, kogukonna ja pereliikmete toetus kraadiõppe ajal}

Kraadiõpingutest rääkides väärtustasid intervjueeritavad enda iseseisvuse kõrval kogukonda ja koostööd. Tähenduslike inimestena kraadiõppe perioodist meenutati kaasõppijaid ja perekonda, samuti väärtuslikke suhtlusvõimalusi kolleegide (sh uurimisrühmade liikmete) ja rahvusvahelise uurijate kogukonna liikmetega. 
Kaasõppijate ja uurimisrühma tuge kirjeldati intervjuudes n-ö koostöötoena, kus ühine töö laboris ja/või uurimisrühmas pakkus õppijatele võimalust tööga seonduva üle mõtteid vahetada. Selliseid kohtumisi pidasid eriti väärtuslikuks eeskätt need uuritavad, kelle juhendaja asus kaugel ning kelle jaoks siinne kogukond pakkus väitekirjaga seoses võimalust kõrvaltvaateks ja tagasisideks. Uurimisrühmades toimunud arutelud kompenseerisid uuritavate kirjelduste kohaselt vajakajäämisi juhendamises. Kolleegidelt uurimisrühmast saadi tuge metoodika väljatöötamisel, uuringu korraldamisel ja ühisartiklite kirjutamisel.

Kaks korda nägin juhendajat [juhendaja Venemaal], aga mul ei olnud sellest sugugi puudust. Sellepärast, et ma töötasin sellel ajal ülikooliga seotud teadusasutuses. /.../ Seal toimusid iseenesest sellised sisulised sisearutelud. Et ma pidin seal aeg-ajalt rääkima, mida ma teinud olen. (Anu)

No mis oli muidugi suureks plussiks, oli see, et minul oli ka võimalus kuuluda sellisesse projekti, rahvusvahelisse projekti, et seda sugugi kõigil doktorantidel ei olnud. Nii et see oli hästi tore, et see toetus oli olemas ja ka ütleme selline artiklite kirjutamise võimalus koostöös, ma ei pidanud üksi siis rabelema ja avastama seda kõike. (Maie)

Intervjuudes meenutati, kuidas toetuse leidmiseks loodi ise näiteks kaasdoktorantidega tugirühm, milles kavandati üksteise töid, arutleti väitekirjaga seonduva üle, hangiti rahalisi vahendeid välismaale raamatukogudesse või konverentsidele sõitmiseks.

Meile tundus, et olime natuke nagu omapead jäetud ja et seda kompenseerida, siis me tegime sellise rühma. /.../ Käisime koos välismaal raamatukogus lugemas ja pärast ajasime mingeid muid rahasid välja, millega kuskil õppida ja käia. Me võrdselt seal raamatukogus pusisime ja õhtuti arutasime. (Alma)

Sisulise akadeemilise dialoogi kõrval meenutati intervjuudes tähtsana kaasõppijate ja kogukonna liikmete moraalset toetust.

Me liikusime kursuseõega. /.../ Neid aineid sai tehtud koos, mis meil olid. Selles suhtes noh et see n-ö social-osa oli olemas. Sai kurdetud ka kõiksuguste probleemide üle, nii õppes kui ka siis oma doktoritöö valmimisel. (Pille) 
Olenemata sellest, kas juhendaja ja kogukonna toetust õpingute ajal tajuti piisavana või mitte, peeti õpingute ajal oluliseks rahvusvahelisse teadlaste kogukonda kuulumist ning väärtustati võimalusi kraadiõpingute jooksul suhelda kohalikust kogukonnast väljaspool olevate teadlastega. Mõnevõrra piiratuna kirjeldasid sellekohaseid võimalusi aspirantuuri ajal õppinud uuritavad, öeldes, et juhul kui ei kuulutud parteisse või oldi tollasele korrale sobimatute tõekspidamistega, siis NSV Liidu Riikliku Julgeoleku Komitee (KGB) huviorbiidis olemine muutis keeruliseks ka reisimise väljapoole Nõukogude Liitu.

Tol ajal nõuti, et aspirant peab olema partei liige, ja mina ei tahtnud parteisse astuda. (Karl)

GB ei lasknud mind välja lihtsalt ja kui ma sinna [lääneriiki] jõudsin, siis oli natukene hilja. Mõni kursusekaaslane, kes parteisse astus, sai õigel ajal. Ma viis aastat taotlesin sõitu ja kui ma sinna jõudsin, siis öeldi, et kuulge, nii hilja, see teema oli meil viis aastat tagasi, praegu me enam seda teadust ei tee. (Tiit)

Aspirantuuri ajast meenutati ka olukordi, kus teadlaste kogukonnaga suhtlemine väljaspool Eestit ei olnud tollaste aspirantide valik. Näiteks tuli olude sunnil kaitsta kandidaaditööd Moskvas või NSV Liidu vabariikides, sest Eestis ei olnud kaitsmiskomisjoni moodustamiseks piisaval hulgal asjaomase valdkonna tippteadlasi. Uuringus osalenud juhendajad meenutasid töö kaitsmist võõras kogukonnas ja keskkonnas, pidades seda märksa pingelisemaks kui töö kaitsmist Eestis.

Stressi oli päris palju. Kusjuures saalis istusid ikka niimoodi, et isamaasõja medalid olid rinnas ja kõlistasid medaleid seal. /.../ Täitsa karmilt suhtuti ikka, esitati ikka igasuguseid küsimusi, et mingit nisukest mängu või värki ei olnud. Neil polnud ei sooja ega külma, kas me saame kraadi või ei saa. Aga kui oli kõik läbi, siis tulid kohalikud ka sealt ja ütlesid, et oi, et ma käisin Eestis 1938. aastal, ma olin Toilas skaudilaagris. Nii et pärast tulid nagu välja ka tõelised mehed, aga algul oli ikka väga karm. (Karl)

Eesti taasiseseisvumisega ja seeläbi avardunud võimalustega muutus keel, milles peale emakeele akadeemilises ringkonnas kirjutati ja suheldi. Kui nõukogude ajal aspirantuuris õppinud kirjeldasid vene keeles rääkimist ja kirjutamist kui vajalikke oskusi õpingutes edasiliikumisel ja teiste teadlastega suhtlemisel, siis võimaluste laienedes muutus inglise keele oskus järjest tähtsamaks suhtlemisel eri riikide teadlastega. Seetõttu meenutati olukordi, 
kus ebapiisav keeleoskus valmistas õppijale piinlikkust, kuid samas ei peetud seda otseselt õpinguid takistavaks teguriks.

Mis minul tegi asja raskeks, oli see, et kuna meie teadus oli ainult ingliskeelne, siis minu inglise keele oskus oli alguses väga kehva. Noh nagu ta tuli sealt sellest nõukogudeaegsest koolist. Lugesin ma küll, kirjutamisega oli muidugi probleeme, aga kõige õudsem oli see, et pidi ju käima ka teaduskonverentsidel ja tegema ettekandeid, ja issand jumal, kuidas ma põdesin, üleüldse kõige rohkem ma põdesin oma inglise keele oskuse pärast, mitte oma teaduslike teadmiste pärast. (Eva)

Uuritavad, kelle õpinguaeg jäi Eesti vabariigi taasiseseisvumise järgsesse aega, kirjeldasid sõite lääneriikidesse konverentsidele ja raamatukogudesse kui head võimalust enesetäienduseks ja akadeemilise kogukonna liikmeks saamisel, samuti kui vajalikku ja väärtuslikku osa üldise silmaringi laiendamisel.

Mul oli võimalus käia, ma arvan kolmel või neljal doktorikooli kursusel põhjamaades. Kutsuti maailma juhtivad teadlased kohale, kuskil nädal aega mingisuguses looduskaunis kohas. Vot need olid tohutult viljastavad ja tohutult arendavad kogemused minu jaoks. No tollel ajal ma ei olnud ju reisinud ka, see oli suur asi ja see arusaamine, et teadus on sotsiaalne ja inimestevahelised suhted on tegelikult need, mis ka teaduses loevad. (Eva)

Uurijate kogukonna kõrval nimetasid uuritavad õpingutes edasiliikumise toetajatena oma pereliikmeid. Pereliikmetelt saadi abi laste hoidmisel töö kirjutamise ja välislähetuste ajal, samuti pakkusid nad moraalset ja materiaalset tuge. Samas oli uuritavaid, kes leidsid, et perekonnaelu takistas õpingutes edasijõudmist, sest korraga oli keeruline toime tulla laste, põhitöö ja õpingutega.

Pisike laps kodus ja teine natuke suurem ees, noh see ikkagi oli ka. Perekond segas. /.../ Et noh see on pühendumise probleem. /.../ Ei ole lihtsalt aega ainult sellele pühenduda. (Maie)

Uurimuse tulemused osutavad, et kraadiõpingute ajale tagasi mõeldes väärtustasid uuritavad nii koostööd kaasõppijate kui ka teiste kogukonna liikmetega. Ühised arutelud kogukonnas andsid muu hulgas võimaluse kompenseerida vajakajäämisi juhendamises ning pakkusid emotsionaalset tuge kraadiõppes edasiliikumiseks. 


\section{Seosed uuritavate kraadiõpingute kogemuse ja praeguse juhendamispraktika vahel}

Eraldi oli uurimuses vaatluse all uuritavate seosed oma kraadiõpingute kogemuse ja praeguse juhendamispraktika vahel. Tulemused osutavad, et kuna uuritavad omistasid sarnastele olukordadele erineva tähenduse, siis kirjeldati ka seoseid õpinguaegse juhendamiskogemuse ja praeguse juhendamispraktika vahel erinevalt. Kuna analüüsi aluseks on teemad, mida juhendajad ise intervjuudes kraadiõpinguteaegse juhendamise ja praeguse juhendamispraktika juures võrdlevalt esile tõid, siis ei pruugi tulemused kajastada juhendajate tegelikku juhendamispraktikat, vaid on pigem juhendajate tõlgendus sellest, milles sarnasusi ja erinevusi nähakse. Põhiteemadena eristusid intervjuudes juhendaja üldine toetav hoiak ja juhendamise sisukus, iseseisvaks uurijaks kujunemine ja õppija töötahe ning kogukonda kuulumise soodustamine.

\section{Juhendaja üldine toetav hoiak ja juhendamise sisukus}

Juhendamiskogemust ja juhendajat meenutades tähtsustasid uuritavad intervjuudes juhendaja avatud ja toetavat suhtlusviisi (olenemata juhendamiskohtumiste sagedusest ja üldisest rahulolust juhendamisega), mille puhul märgiti, et seda on püütud ka oma juhendamisse üle võtta. Samuti väärtustati ja meenutati positiivsena võrdsel tasandil suhtlust. Kui intervjueeritav oli õpingute ajal kogenud juhendaja toetust ning osalenud sisukas ja edasiviivas akadeemilises diskussioonis juhendamiskohtumistel, siis peeti oluliseks ka oma doktorantidele õppimiseks soodsa arengukeskkonna võimaldamist kõigil õpinguetappidel.

Tema [endine juhendaja] väga palju arutas ja nisukene vestlus toimus kogu aeg ja seda ma olen nüüd kindlasti kasutanud ka oma üliõpilastega. /.../ Juhendaja lihtsalt nagu üritas minu seda nisukest tervikut luua ja nüüd samamoodi ma siis üritan oma juhendatavatega, kui me nüüd kirjutame need artiklid, siis me üritame juba eelnevalt planeerida, et ta oleks lõppkokkuvõttes tervik see töö. (Riina)

Juhendamise sisukusega seoses väljendati ka seda, milles juhendajana püütakse oma juhendajast erineda. Uuritavad, kes pidasid õpinguaegset juhendamist ebapiisavaks, ütlesid, et oma juhendamispraktikas püüavad nad juhendatavate jaoks aega leida, süveneda kraadiõppuri töösse ning suunata protsessi konstruktiivse ja edasiviiva tagasiside kaudu. 
Kui ta ikkagi tahab sinu poole pöörduda, siis sa pead selle aja leidma, ja kui ta saadab sulle oma töö, siis sa loed seda kasvõi öösel kell 3, aga sinu taha ei tohi see asi pidama jääda. Kui sa oled kellegi kodustanud, siis sa pead tema eest hoolitsema ja vastutama. (Maie)

\section{Iseseisvaks uurijaks kujunemine ja õppija töötahe}

Juhendaja hoiaku ja juhendamise sisukusega seostub iseseisvaks uurijaks kujunemine, mis on mõneti vastuoluline teema, sest juhendajad suhtusid kirjutamisprotsessi erinevalt. Uuritavate hulgas oli neid, kes kirjeldasid õpinguteaegset üksiolekut ja iseseisvalt töö kirjutamist kui loomulikku ja meeldivat protsessi, mis toetas iseseisvaks uurijaks kujunemist, seega käsitlesid nad saadud kogemust positiivsena. Üksi toimetamise vajalikkusest juhinduvad uuritavad ka oma juhendatavaid juhendades. Näiteks oodatakse juhendatava initsiatiivi juhendamiskohtumiste kokkuleppimisel.

Ma tundsin väga hästi, kui mind rahule jäeti ja mul lasti teha seda, mis ma tahtsin, ja seepärast ma ei ole kedagi torkinud oma juhendatavatest, kui nad ei tule näiteks kord kuus kohtuma. Et võib-olla on nad ka samasugused nagu mina. (Pille)

Samas leidsid uuritavad, kes ootasid juhendaja suuremat sekkumist ja tuge, et ise juhendades püütakse pakkuda juhendatavale igakülgset toetust.

Et tegelikult on ikkagi väga vaja seda tuge ja niisugust kinnitust. /.../ Kui sul ei ole juhendajat või sind ei juhendata lihtsalt, siis sa oledki nagu see kadunud siil udus, sa ei tea, kas sa teed õigeid asju, vajalikke asju, mida sa üldse tegema pead, kuhu suunas minna. /.../ See ei tähenda seda, et ta sulle ütleb, aga ta küsibki tegelikult neid õigeid küsimusi, et igal juhul aidata leida see teeots ja siis jälgida, et ta seal tee peal kõrvale ei astu, et nagu Punamütsike läheb lilli korjama ja siis ei jõuagi vanaema juurde, et jõuaks ikka selle doktoritööni välja. (Kati)

Töötahte ja õpingutele pühendumise kohta sõnasid mitmed uuritavad, et nad võrdlevad ennast kraadiõppurina oma praeguste doktorantidega. Leiti, et doktorandid on nendega sarnased ja seetõttu on valitud ka samasugune juhendamisviis. Ent leidus ka uuritavaid, kes ei mõistnud, kuidas nende praegused doktorandid ei suuda nii intensiivselt ja innukalt töötada nagu nemad omal ajal. Juhendatavatelt oodatakse seega suuremat motivatsiooni, pühendumist, töökust ja aja planeerimise oskust. 
Mis on minu kui juhendaja põhiprobleem, et ma eeldan, et kõik on sama töökad, et suudavad öö otsa üleval olla, et ma ei tule selle peale, et mõned inimesed ei suuda. Nagu minu ema ütles, et tõused kell 4 ülesse ja jõuad kõik ära teha, aga mõni inimene lihtsalt ei jaksa, mina jaksan, kui mul on vaja tööd teha. (Kaie)

Tulemused osutavad, et iseseisvuse ja üksi töötamise puhul kandub sama juhendamismuster edasi ka praegusesse juhendamispraktikasse, kui üksi töötamine tulenes kraadiõppuri enda soovist saada võimalikult iseseisvalt hakkama. Juhtudel, kus õpingute ajal tunti juhendamisest puudust, püüavad uuritavad praeguses juhendamispraktikas juhendatavaid enam toetada.

\section{Kogukondliku kuuluvuse soodustamine}

Uuringus osalenud juhendajad pidasid oma õpinguajale tagasi mõeldes oluliseks ja vajalikuks juhendaja toetust teadlaste kogukonna liikmeks saamisel. Mitmed uuritavad tõid esile, kuidas juhendajad leidsid õpingute ajal võimalusi, et kraadiõppur saaks oma teemat tutvustada konverentsidel ja seminaridel ning selle käigus tutvuda teiste uurijatega. Uuritavad, kes olid õpingute ajal saanud selle kogemuse osaliseks, pidasid oluliseks võimaldada seda ka oma doktorantidele.

Üks asi, mis tuleb minu enda doktorantuuriajast kaasa, mida ma olen püüdnud noortele rääkida, et tuleb käia, tuleb suhelda ka teaduseväliselt nendesamade inimestega, et tuleb luua sidemeid. Sa õpid tundma erinevaid inimkaraktereid ja õpid nagu elus toime tulema paremini. (Eva)

Uuritavate kirjeldustes selle kohta, kuidas nad toetavad oma praegusi doktorante teadlaste kogukonna liikmeks saamisel, oli rõhuasetus rahvusvaheliste kontaktide loomisel. Teaduskoostöö puhul mainiti vaid üksikutel kordadel, et tähtis on teha koostööd ja moodustada võrgustik teiste Eesti ülikoolide teadlastega. Ka oma õpinguaja kirjeldustes nimetati koostööd teiste Eesti ülikoolide teadlastega harva.

Uuritavad, kelle juhendaja ei toetanud juhendatava sotsialiseerumist ja erialakogukonnaga liitumist, osutasid, et mõistavad juhendajana sotsialiseerumise ja teadlaste kogukonda kuulumise olulisust ning püüavad oma juhendatavaid kogukonna liikmeks saamisel toetada (nt käies koos konverentsidel).

Et tookord ma mäletan, et ma mingitele konverentsidele läksin ka ise, et ta ei suunanud mind, vaid esimesele konverentsile, et jah ma nagu 
mingite teiste allikate kaudu leidsin mingid konverentsid, kuhu ma läksin. Et nüüd ma olen nagu püüdnud, et me käiksime nagu sarnastel konverentsidel ja oleks nagu selline ühine konverentsikogemus. (Alma)

Intervjueeritavad, kes kirjeldasid oma õpinguaega kui tööd projektimeeskondades ja leidsid, et see toetab õpingutes edasijõudmist, väljendasid intervjuudes soovi pakkuda seda võimalust ka oma juhendatavatele. Need, kes ei kuulunud projektimeeskondadesse, pidasid samuti uurimisrühma kuulumist kraadiõpinguid lihtsustavaks teguriks ning soovisid, et nende juhendajad kuuluksid mõnda uurimisprojekti.

Juhendajal endal jooksis kõrval üks grant, kus ma olin natukene ka osaline. /.../ See [doktorantide projektidesse kuulumine] oleks jah päris suur abi ja noh ma olen mõelnud ka praegu oma juhendatavate puhul, et kui nad tulevad sinuga uurimisprojekti kaasa, nad saavad andmeid ja see oleks päris suur pluss doktorandile, et juhendaja grandid, juhendaja uuringud, kui ta saab selles oma kindla osa teha, et see oleks suur pluss. (Laur)

Seega võib öelda, et kogukonda kuulumine on olnud uuringus osalenud kraadiõppuritele tähtis ning seda väärtustades püütakse intervjueeritavate sõnul ka oma doktorantidele luua võimalusi sotsialiseerumiseks akadeemilises kogukonnas.

\section{Arutelu}

Uurimused on näidanud, et juhendajate arusaamad juhendamise erinevate tegurite kohta kujundatakse varasema õppimise ja teadustöö kogemuse põhjal (nt Delamont et al., 1998; Lee, 2008). Seetõttu seati siinse uurimuse eesmärgiks kirjeldada Eestis tegutsevate juhendajate kujunemise tausta ning osutada võimalikele seostele nende kraadiõpingute kogemuste ja juhendamispraktika vahel. Juhendajate kogemustest, mis omandati eri ajal kraadiõppes õppides, ilmnes mitmeid ajastutele omaseid jooni. Tähtis oli ka õpingutele pühendumise võimalus, iseseisvus väitekirja kirjutamisel ja kraadiõppuri enda töötahe, mis ei olenenud õpinguajast. Väitekirja valmimise protsessi kirjeldades toodi peale endaga seotud tegurite esile ka juhendaja ja kogukonna tähtsus ning tähendus. Juhendajate intervjuude põhjal võib öelda, et enda juhendamispraktikasse on püütud võtta mitmeid tegevusi, mis uuritavate kirjelduste järgi toetasid nende edasijõudmist 
kraadiõppes, sh avatud ja võrdsel alusel suhtlemine juhendatavaga ning tema toetamine iseseisvaks uurijaks kujunemisel. Samuti nimetati intervjuudes omadusi (nt pealiskaudsus ja hoolimatus juhendatavale tagasiside andmisel), mille poolest soovitakse oma juhendajast erineda.

Varasemate uurimuste ja praeguse Eesti doktoriõppe konteksti valguses pakuvad huvi mõningad uurimistulemused, mida kirjeldatakse allpool lähemalt. Kuna need põhinevad uuritavate meenutustel, kuid meenutamine on oma olemuselt retrospektiivne, ei pruugi need anda olukorrast täpset ülevaadet (Stubb et al., 2011) ning seda tuleb uurimuse piiranguna ka arvesse võtta.

Juhendatavate kirjelduste järgi võib enamiku uurimuses osalenutest liigitada juhendajast sõltumatu juhendatava rühma (vt Kam, 1997): nad töötavad enamasti üksinda ning kontakteeruvad ja konsulteerivad juhendajaga üksnes vajaduse korral. Varasemad uurimused on andnud vastupidiseid tulemusi. Näiteks leidsid Brew ja Peseta (2004), et regulaarsed kohtumised on õpingutes edasijõudmise seisukohalt määrava tähtsusega. Ka Lee (2008) uurimuses toodi muu hulgas esile funktsionaalset juhendamisstiili, mille puhul juhendaja juhib protsessi, andes selgeid suuniseid ja ülesandeid, mis omakorda aitavad kraadiõppuril õpingutes edasi liikuda. Seevastu siinses uuringus osalenud kirjeldasid pigem seda, kuidas nende enda tööstiil juhendatavana ühtis funktsionaalse stiili tunnustega. Õppijana seati endale vaheeesmärke ja tähtaegu ning määrati kohtumisi juhendajaga. Osaliselt võis selle põhjuseks olla vahemaa - distants juhendaja ja juhendatava vahel ning ajastule omaselt aeglasem infoliikumine, mida uuritavad intervjuudes mõneti üllatuslikult õpingutega seoses ei meenutanud. Samas võis see olla tingitud ka sellest, et praeguste juhendajate juhendatavaks olemise ajal oli kraadiõppes õppimine praegusest vabamalt reguleeritud, nt tänapäeval avaldatakse doktorantidele tugevamat survet, et nad lõpetaksid õpingud nominaalajaga, rakendatakse atesteerimist (vt nt Eesti Ülikoolide kvaliteedi ..., 2003; Kehm, 2004).

Nii nagu ilmnes Kami (1997) uurimusest, näitavad ka praegused uurimistulemused, et kraadiõppurid vajavad toetust erineval määral ja tõlgendavad juhendamist seetõttu erinevalt. Iseseisvust kraadiõpingutes kirjeldati intervjuudes kas vaba valiku või paratamatusena. Sarnaseid juhendamissituatsioone tajuti erinevalt, mistõttu leidub ka erinevusi juhendajate juhendamispraktikas. Kui oma juhendatavatele omistatakse endaga sarnaseid omadusi (nt iseseisvus, soov üksi töötada, hea planeerimisoskus) ja varasemat praktikat kantakse edasi oma juhendamisse, ei pruugi see osutuda doktoriõppe muutunud oludes otstarbekaks. Kuigi Lee (2008) järgi on juhendamise seisukohalt oluline arendada kraadiõppuri kriitilist 
mõtlemist ja toetada tema iseseisvust, mida soodustabki doktorandi initsiatiivist lähtuv juhendamine, ei tohiks juhendajad kõrvale jätta ka teisi juhendamisstiile (nt funktsionaalset stiili), mille rakendamist peetakse vajalikuks just pingelisemaks muutunud nominaalajaga lõpetamiste surve tõttu (vt Lee, 2008). Lisaks ei pruugi juhendatava initsiatiivi ootamine olla põhjendatud ka seetõttu, et kraadiõppur ei mõista alati ka ise, millal ja milles ta abi vajab (Manathunga, 2005). Juhendaja välise surve puudumine (isegi siis, kui õppijad soovivad oma tempos liikuda ja initsiatiivi enda käes hoida) võimaldab doktorantidel kohtumisi edasi lükata, mistõttu ei ole ka juhendajal doktorandi töö edenemisest piisavat ülevaadet. Regulaarsus kohtumistes aitaks aga juhendajal doktorandi tööga enam kursis olla ning hoida mõlemapoolset uurimishuvi (Pole et al., 1997). Seetõttu pakub juhendamiskohtumiste sagedusega seonduv teave väärtuslikku mõtteainet nii juhendajatele kui ka doktoriõppe arendajatele. Kuna praegusest uurimusest selgus, et juhendajate endi kogemused juhendatavaks olemise ajast on erinevad ning kogemusele omistatakse erinevaid tähendusi, siis tuleks pakkuda juhendajatele võimalust erinevate koolituste ja seminaride käigus oma kogemuste üle arutleda, juhendamispraktikat analüüsida ning saada seeläbi teadlikumaks juhendamisviiside mitmekesisusest (nt Dysthe et al., 2006; Lee, 2008) ja nende kombineerimise vajalikkusest.

Uurimistulemused osutasid, et uuritavad tähtsustasid kogukonna osa nii õpingutes edasijõudmisel kui ka akadeemilise kogukonna liikmeks saamisel. Kogukonda kuulusid kolleegid, uurimisrühmade liikmed ja kaasõppijad. Nii nagu ilmnes Golde (2005) ja Gardneri (2009) uurimusest, tegid loodusteaduste valdkonna juhendajad kaasõppijate ja juhendajaga tihedat koostööd, seevastu haridusvaldkonna esindajatest oli uurimisrühmas töötamise võimalus vähestel ning enamasti töötati oma uurimisteemaga üksinda. Varasemates uurimustes (nt Lahenius, 2012) on osutatud, et üksi töötades on oht ilma jääda väärtuslikest koostöökogemustest praktikakogukonnas. Praegune uuring näitas, et toetava kogukonna puudusel hakati ise seda enda ümber looma. Võimalik, et seda lihtsustas õpingute kõrvalt töötamine ülikoolis ning töökohustustest tulenev võimalus suhelda akadeemilise kogukonnaga. Kuna viimastel aastatel on Eesti doktoriõpet puudutavad uurimused (Eamets et al., 2014; Ots et al., 2012) viidanud ühe õpingute pikenemise või katkestamise põhjusena doktorantide töötamisele väljaspool ülikooli, siis võib praegustel doktorantidel olla ka keerulisem luua õpinguid toetavat kogukonda (sh kogukonda, kes pakub toetust ebapiisava juhendamissuhte korral). Kuigi uuringus osalejad tõid esile, et nende jaoks on oma praegusi doktorante juhendades oluline toetada nende kuulumist kogukonda, siis ei tähenda see veel, et doktorandid tunneksid end kogukonna liikmetena, mida näitavad 
doktoriõpingud katkestanud õppijate seas tehtud uuringud (nt Leijen, Lepp, \& Remmik, ettevalmistamisel). Seetõttu tuleks juhendamissuhtes pöörata tähelepanu doktorandi sotsialiseerumisvõimalustele ning kultuuri omandamisele (Lee, 2008). Üks võimalus on rakendada juhendamisel Dysthe jt (2006) välja pakutud mitut koostöövormi (individuaalne juhendamine, rühmajuhendamine, tingimuste loomine doktorantide omavahelisteks aruteludeks) paralleelselt ja senisest ulatuslikumalt. Ülikoolide koostöö tõhustamine, nt ühise juhendamise või ühiste uurimisrühmade loomise kaudu, võiks pakkuda samuti aruteluainest doktoriõppe arendajatele.

Tulemused osutavad, et kõigi uuritavate jaoks oli õpingute eduka lõpetamise üks eeldusi võimalus pühenduda kraadiõppele. Kuigi intervjueeritavad olid edukalt õpingud lõpetanud, peeti õpinguid takistavaks teguriks muu hulgas töötamist ülikoolis, kui väitekirja teema ei olnud kraadiõppuri töökohustustega seotud. Eamets jt (2014) leidsid, et doktorantide edasijõudmist doktoriõppes takistab jätkuvalt liigne hõivatus põhitööga, mis ei ole seotud doktoritööga. Arvestades meie uuritavate õpinguaega (õpingute lõpetamine aastatel 1970-2008), võib öelda, et nendele probleemidele doktoriõppe korralduses ei ole senini suudetud lahendusi leida. Seega tuleks mõelda, mida saaks ülikool või riik teha, et kraadiõppuril oleks võimalik õpingutele rohkem pühenduda. Kuigi Eestis on viimastel aastatel püütud astuda mõningaid samme, nt pakkuda doktoriõppes õppijatele võimalust saada nooremteaduriks (Riigikogu, 2011), on jätkuvalt teravalt üleval õppijate sotsiaalmajandusliku toimetuleku ja seega kraadiõppele pühendumise küsimus (Ots et al., 2012).

Artikli autorid leiavad, et uurimistulemused annavad alust kavandada järgnevaid uurimusi, mis võiksid keskenduda juhendajate ja juhendatavate juhendamiskohtumiste ajendite, sageduse ja sisu uurimisele mõlema poole vaatenurgast. Kuna tulemused näitavad, et praeguste juhendajate endi juhendamiskohtumised toimusid peamiselt juhendatavate initsiatiivil ja nende tajutud vajaduse korral, siis vajaks uurimist, kuivõrd peetakse vajalikuks viimasel ajal doktoriõppe arengusoovitustes rõhutatud kohtumiste regulaarsust ja suuremat tõhusust (vt nt Eamets et al., 2014), seda ka erineva taustaga uuritavate puhul (vt nt Ots et al., 2012). Huvitavat lisaväärtust valdkonna uurimisse võiksid pakkuda ka fotointervjuud, mida on kasutanud näiteks Karm ja Remmik (2013) õppejõudude õpetamisarusaamu uurides.

Kuigi siinseid uurimistulemusi ei saa käsitleda üldistatavana, annab artikkel autorite arvates head mõtteainet nii juhendajatele, doktoriõppe arendajatele kui ka doktorantidele. Juhendajatel on võimalik tõmmata paralleele oma juhendamiskogemuste ja -praktikaga ning mõtiskleda selle üle, milles seisnevad doktorantide juhendamise sarnasused ja erinevused võrdluses 
varasema juhendamisega ning kuivõrd ja mis osas on oma kogemuse ülekandmine õigustatud. Doktoriõppe arendajad saavad artiklist kinnitust, et praeguste juhendajate kogemused, mida nad on saanud juhendatavaks olemise ajast, on väga erinevad ning seetõttu tuleks juhendajaid toetada seminaride ja koolituste kaudu ning laiendada seeläbi nende arusaama juhendamisviisidest ja eesmärkidest. Doktorantidele võiks artikkel pakkuda mõtteainet, kuivõrd oluline on kraadiõpingute eduka läbimise seisukohalt huvi uurimistöö vastu, ja innustada neid edenema kraadiõppes, järgides artikli pealkirjana esitatud motot „Läbi raskuste tähtede poole”.

\section{Tänuavaldus}

Artikli valmimist toetas Euroopa Sotsiaalfondi haridus- ja kasvatusteaduste doktorikool (1.2.0401.09-0070) ja Euroopa Sotsiaalfondi Eduko programm. Artikli autorid tänavad Tartu Ülikooli akadeemilist sekretäri IvarIgor Saarniitu ja juhendajaid sisukate intervjuude eest ning anonüümseid retsensente edasiviiva ja julgustava tagasiside eest.

\section{Kasutatud kirjandus}

Barnes, B. J., \& Austin, A. E. (2009). The role of doctoral advisors: A look at advising from the advisor's perspective. Innovative Higher Education, 33(5), 297-315. http://dx.doi.org/10.1007/s10755-008-9084-x

Brew, A., \& Peseta, T. (2004). Changing postgraduate supervision practice: A programme to encourage learning through reflection and feedback. Innovations in Education and Teaching International, 43(1), 5-22. http://dx.doi.org/10.1080/1470329032000172685

Delamont, S., Parry, O., \& Atkinson, P. (1998). Creating a delicate balance: The doctoral supervisor's dilemmas. Teaching in Higher Eduation, 3(2), 157-172. http://dx.doi.org/10.1080/1356215980030203

Dysthe, O., Samara, A., \& Westrheim, K. (2006). Multivoiced supervision of Master's students: A case study of alternative supervision practices in higher education. Studies in Higher Education, 31(3), 299-318. http://dx.doi.org/10.1080/03075070600680562

Eamets, R., Tamm, K., Tamm-Klaos, D., Aksen, M., Kärner, A., \& Kindsiko, E. (2014). Doktoriõppe tulemuslikkuse analüüs. Uuringu 2.4 lõppraport. Külastatud aadressil http://tips.ut.ee/img/image/TIPSraportdoktorippetulemuslikkusest27.03.141.pdf.

Easterby-Smith, M., Thorpe, R., \& Lowe, A. (2002). Management research: An introduction (2nd ed.). London: Sage Publications.

Eesti ülikoolide kvaliteedi hea tava lepe (2003). Külastatud aadressil http://www.ern. ee/images/dokumendid/kvaliteedilepe/allkirjastastud_head_tavad.pdf. 
Gardner, S. K. (2009). Student and faculty attributions of attrition in high and lowcompleting doctoral programs in the United States. Higher Education, 58(1), 97-112. http://dx.doi.org/10.1007/s10734-008-9184-7

Gardner, S. K. (2010). Contrasting the socialization experiences of doctoral students in high- and low-completing departments: A qualitative analysis of disciplinary contexts at one institution. The Journal of Higher Education, 81(1), 61-81. http://dx.doi.org/10.1353/jhe.0.0081

Golde, C. M. (2005). The role of the department and discipline in doctoral student attrition: Lessons from four departments. The Journal of Higher Education, 76(6), 669-700. http://dx.doi.org/10.1353/jhe.2005.0039

Grant, B., \& Graham, A. (1999). Naming the game: Reconstructing graduate supervision. Teaching in Higher Education, 4(1), 77-89. http://dx.doi.org/10.1080/1356251990040105

Halse, C. (2011). 'Becoming a supervisor': The impact of doctoral supervision on supervisors' learning. Studies in Higher Education, 36(5), 557-570. http://dx.doi.org/10.1080/03075079.2011.594593

Hemer, S. R. (2012). Informality, power and relationships in postgraduate supervision: Supervising $\mathrm{PhD}$ candidates over coffee. Higher Education Research \& Development, 31(6), 827-839. http://dx.doi.org/10.1080/07294360.2012.674011

Hockey, J. (1994). New territory: Problems of adjusting to the first year of a social science PhD. Studies in Higher Education, 19(2), 177-190. http://dx.doi.org/10.1080/03075079412331382027

Ives, G., \& Rowley, G. (2005). Supervisory selection or allocation or continuity of supervision: Ph.D. students' progress and outcomes. Studies in Higher Education, 30(5), 535-555. http://dx.doi.org/10.1080/03075070500249161

Kam, B. H. (1997). Style and quality in research supervision: The supervisor dependency factor. Higher Education, 34(1), 81-103. http://dx.doi.org/10.1023/A:1002946922952

Karm, M., \& Remmik, M. (2013). Algajate õppejõudude õpetamisarusaamad fotointervjuude põhjal. Eesti Haridusteaduste Ajakiri, 1, 124-155. http://dx.doi.org/10.12697/eha.2013.1.07

Kehm, B. M. (2004). Developing doctoral degrees and qualifications in Europe: Good practice and issues of concern - A comparative analysis. In J. Sadlak (Ed.), Doctoral studies and qualifications in Europe and the United States: Status and prospects (pp. 279-296). Bucharest: UNESCO-CEPES.

Kiley, M., \& Mullins, G. (2005). Supervisors' conceptions of research: What are they? Scandinavian Journal of Educational Research, 49(3), 245-262. http://dx.doi.org/10.1080/00313830500109550

Kärner, A. (2008). Doctoral supervision: Towards new concepts and dilemmas. In J. Mikk., M. Veisson \& P. Luik (Eds.), Reforms and innovations in Estonian education (pp. 61-76). Frankfurt am Main etc.: Peter Lang.

Lahenius, K. (2012). Communities of practice supporting doctoral studies. The International Journal of Management Education, 10(1), 29-38. http://dx.doi.org/10.1016/j.ijme.2012.02.003

Lave, J., \& Wenger, E. (1991). Situated learning: Legitimate peripheral participation. Cambridge: Cambridge University Press. http://dx.doi.org/10.1017/CBO9780511815355 
Lee, A. (2008). How are doctoral students supervised? Concepts of doctoral research supervision. Studies in Higher Education, 33(3), 267-281. http://dx.doi.org/10.1080/03075070802049202

Leijen, Ä., Lepp, L., \& Remmik, M. (ettevalmistamisel). Doktoriõppe katkestajad doktoriõppe protsessist ja katkestamisega seotud teguritest.

Lepp, L., Karm, M., \& Remmik, M. (2013a). Supervisors' activities in supporting PhD students in the supervisory process. In E. Saar \& R. Mõttus (Eds.), Higher education at the crossroad: The case of Estonia (pp. 247-265). Frankfurt am Main etc.: Peter Lang.

Lepp, L., Remmik, M., Karm, M., \& Leijen, Ä. (2013b). Supervisors' conceptions of doctoral studies. Trames: Journal of the Humanities and Social Sciences, 17(4), 401-415. http://dx.doi.org/10.3176/tr.2013.4.06

Lovitts, B. E. (2001). Leaving the ivory tower: The causes and consequences of departure from doctoral study. Lanham: Rowman \& Littlefield.

Mainard, T., van der Rijst, R., van Tartwijk, J., \& Wubbels, T. (2009). A model for the supervisor-doctoral student relationship. Higher Education, 58(3), 359-373. http://dx.doi.org/10.1007/s10734-009-9199-8

Manathunga, C. (2005). Early warning signs in postgraduate research education: A different approach to ensuring timely completions. Teaching in Higher Education, 10(2), 219-233. http://dx.doi.org/10.1080/1356251042000337963

Martinsuo, M., \& Turkulainen, V. (2011). Personal commitment, support and progress in doctoral studies. Studies in Higher Education, 36(1), 103-120. http://dx.doi.org/10.1080/03075070903469598

Ots, A., Leijen, Ä., \& Pedaste, M. (2012). The relationship between doctoral students' progress in studies and coping with occupational and family responsibilities. In J. Mikk, P. Luik \& M. Veisson (Eds.), Lifelong learning and teacher development (pp. 130-145). Frankfurt am Main etc.: Peter Lang.

Phillips, E., \& Pugh, D. S. (2000). How to get a PhD: A handbook for students and their supervisors (3rd ed.). Buckingham: Open University Press.

Pole, C. J., Sprokkereef, A., Burgess, R. G., \& Lakin, E. (1997). Supervision of doctoral students in the natural sciences: Expectations and experiences. Assessment \& Evaluation in Higher Education, 22(1), 49-63. http://dx.doi.org/10.1080/0260293970220104

Pyhältö, K., Stubb, J., \& Lonka, K. (2009). Developing scholarly communities as learning environments for doctoral students. International Journal for Academic Development, 14(3), 221-232. http://dx.doi.org/10.1080/13601440903106551

Riigikogu (1995). Ülikooliseadus. Riigi Teataja I 1995, 12, 119. Külastatud aadressil https://www.riigiteataja.ee/akt/28729.

Riigikogu (2011). Teadus- ja arendustegevuse korralduse seaduse muutmise seadus. Riigi Teataja I 16.03.2011, 3. Külastatud aadressil https://www.riigiteataja.ee/akt/116032011003.

Ryan, G. W., \& Bernard, H. R. (2003). Techniques to identify themes. Field Methods, 15(1), 85-109. http://dx.doi.org/10.1177/1525822X02239569

Saarniit, I-I. (2014). Kraadiõppe korraldusest ülikoolis ajalooliselt. M. Remmik. [Helisalvestis, 14.01.2014]. 
Sambrook, S., Stewart, J., \& Roberts, C. (2008). Doctoral supervision ... a view from above, below and the middle! Journal of Further and Higher Education, 32(1), 71-84. http://dx.doi.org/10.1080/03098770701781473

Siilivask, K., \& Palamets, H. (1982). Tartu Ülikooli ajalugu III 1918-1982. Tallinn: Eesti Raamat ja Valgus.

Sinclair, M. (2004). The pedagogy of 'good' PhD supervision: A national cross-disciplinary investigation of PhD supervision. Australia: Commonwealth of Australia.

Stubb, J., Pyhältö, K., \& Lonka, K. (2011). Balancing between inspiration and exhaustion: PhD students experienced socio-psychological well-being. Studies in Continuing Education, 33(1), 33-50. http://dx.doi.org/10.1080/0158037X.2010.515572

Vassil, K., \& Solvak, M. (2012). When failing is the only option: Explaining failure to finish PhDs in Estonia. Higher Education, 64(4), 503-516. http://dx.doi.org/10.1007/s10734-012-9507-6

Vilkinas, T. (2002). The PhD process: the supervisor as manager. Education + Training, 44(3), 129-137. http://dx.doi.org/10.1108/00400910210424337

Wisker, G. (2001). The postgraduate research handbook: Succeed with Your MA, MPhil, EdD and PhD. Basingstoke: Palgrave. 


\section{Lisa 1}

\section{Poolstruktureeritud intervjuu kava}

Rääkige, kuidas Teid juhendati.

- Kirjeldage, kuidas Teist sai doktorant/aspirant.

- Kirjeldage, millised olid Teie kraadiõpingud.

- Kirjeldage enda ja juhendaja töökorraldust kraadiõppe ajal.

- Mida Te juhendajas eriti kõrgelt hindasite? Põhjendage.

- Mille poolest tahaksite oma juhendajast erineda?

- Kuidas Teie kraadiõppekogemus on mõjutanud teie juhendamispraktikat? Tooge näiteid.

- Mida tegi Teie juhendaja juhendamisel samal viisil nagu Teie nüüd? Tooge näiteid ja põhjendage.

- Mida teete Teie juhendajast erinevalt ja miks? Tooge näiteid ja põhjendage. 


\title{
Through hardships to the stars: Experiences of doctoral thesis supervisors about their doctoral studies and connections with their supervising practice
}

\author{
Liina Lepp ${ }^{a}$, Marvi Remmik ${ }^{a 1}$, Äli Leijen ${ }^{a}$, Mari Karma \\ ${ }^{a}$ University of Tartu, Institute of Education
}

\section{Summary}

\section{Introduction}

In the past few decades there has been considerable attention paid to developing and increasing the effectiveness of doctoral studies. It has been noted in several studies (e.g. Barnes \& Austin, 2009; Delamont et al., 1998; Lee, 2008) that supervisors' conceptions of different aspects of supervision are formed during their previous study and research experience. Therefore, it has been found that one of the important factors affecting the success of supervision is the way the supervisor him/herself had been supervised in the past.

Doctoral students differ in terms of their knowledge and skills, personal background, but also of their family and work commitments (see more e.g. Ots et al., 2012). Therefore, they also have different expectations and needs concerning supervision (see more e.g. Kam, 1997). Martinsuo and Turkulainen (2011) and Kam (1997) have concluded that the success of postgraduate studies is determined by the reciprocal effect between the doctoral student's expectations and qualities and the supervisor's supervising activities and conceptions.

From the supervisees' perspective, the supervisor's comprehensive domain knowledge (e.g. Mainard et al., 2009) and thorough knowledge about the research methodology in the domain (Easterby-Smith et al., 2002) is seen as the perquisite for successful supervision. According to Brew and Peseta (2004), the supervisor has to be interested in supervising, has to have clear aims and expectations towards supervisee's research and supervision, and has to organize productive meetings.

1 Institute of Education, Faculty of Social Sciences and Education, University of Tartu, Salme 1a, 50103 Tartu, Estonia; marvi.remmik@ut.ee 
Lee (2008) has found that due to doctoral student's academic development throughout their studies, different types of support are needed at different stages. Adjusting the supervisory style according to doctoral student's academic development enables the supervisee to become an independent researcher (see more Sinclair, 2004). If the supervisee's expectations and needs are concurrent with supervisor's activities, then the supervisee is more satisfied with supervision (Lee, 2008).

One of the important factors impacting the doctoral student's satisfaction with postgraduate studies is the relationship between a doctoral student and a supervisor (Grant \& Graham, 1999). Relationships positively perceived by doctoral students foster their success and advancement in their studies, while relationships negatively perceived by students negatively impact their studies (Phillips \& Pugh, 2000).

In the process of doctoral studies, a doctoral student has to acquire the domain-specific values, mentality, norms, knowledge and skills, which are needed for succeeding in the scientific community (Gardner, 2010). Lahenius (2012) finds that a lack of opportunities for cooperation can cause a doctoral student to miss out on the experience of working in the community and, therefore, it is important to find this type of opportunity also for doctoral students who work individually.

The aim of this study is to describe the background of the formation of supervisors and to bring out the possible connections they perceive between their own postgraduate study experiences and their supervisory practices. We sought answers to the following research questions in our study:

1) Which activities and events do supervisors bring out as important from their own postgraduate study time?

2) Who and in which roles do supervisors bring forth as meaningful people when talking about their postgraduate studies?

3) Which connections do supervisors describe between their own postgraduate study experience and their current supervising practice?

\section{Methodology}

The study's sample consisted of 21 supervisors from two Estonian universities. The majority of the participants were working as professors or associate professors. Ten participants had completed their postgraduate studies before Estonia regained its independence in 1991, 11 supervisors had completed their studies in the Republic of Estonia.

The data was collected using semi-structured interviews. To find out about participants' experiences of their postgraduate studies, the general 
question „Please tell us how you were supervised," which was followed by questions according to the interview plan and clarifying questions, were asked. All the interviews were fully transcribed. To protect the participants' identities, supervisors and people mentioned in the interviews were given pseudonyms.

The data was analyzed using qualitative thematic data analysis techniques. The thematic analysis consisted of discovering themes and sub-themes and deciding which themes were important in the context of this research. Two authors undertook parallel identification of themes and division of themes into larger categories.

\section{Major results and discussion}

The results demonstrated that opportunities for dedicating themselves to postgraduate studies differed among the interviewees. Mainly economic reasons were described as the reason for working during the studies. While previous studies about the lengthening and discontinuation of postgraduate studies (e.g. Ots et al., 2012) have shown that the reason for prolongation of postgraduate studies is various non-academic commitments, our research findings show that work at the university also had been experienced as an obstruction if the dissertation topic was not connected with work commitments.

The will to work and managing alone were aspects recalled with pride from study times. Working alone on a dissertation was described in interviews as a free choice or inevitability. Similarly to Kam's (1997) study, when analyzing the supervisory relationship in terms of supervisee's expectations and needs, the results of the present study demonstrate that postgraduate students' need for support differs. The majority of participants can be regarded as representatives of the non-dependent supervisee (Kam, 1997) category, where the supervisee had an expectation for constructive criticism, but where the conductive party in the supervisory process was not the supervisor, but rather the supervisee as being the one setting the mid-term goals and initiating contact with the supervisor in relation to supervision. The supervisor was valued as an academic dialogue partner and feedback provider. If the interviewees had themselves felt shortcomings related to that in the past, they expressed the wish to do better themselves as supervisors.

The study's results indicated that participants' descriptions about opportunities for socializing and co-operation during postgraduate studies differed, but no lack of community support was felt. The community 
comprised of colleagues, members of research groups and, depending on the supervisor's geographical location, also a supervisor (if supervisor was located in Russia, then the supervisee's community was nevertheless in Estonia, consisting of colleagues). Based on the interviewees' descriptions it can be noted that with regard to the frequency of contact with the community, the study results are in line with Golde's (2005) and Gardner's (2009) studies according to which, the supervisors from natural sciences described working in close contact with fellow doctoral students and supervisor, while only few participants from humanities had had the chance to move forward in research groups while studying and they mostly worked alone. While previous studies (e.g. Lahenius, 2012) have discussed whether and to what extent working individually cause one to miss out on valuable collaboration experience in the community of practice, then the present study demonstrated that if postgraduate students work in a research institution or in a university already while studying, as our interviewees did, then support is received from colleagues and fellow students. According to the interviewees, the community's support in the form of research groups, as well as support from fellow students and family facilitates their completion of postgraduate study.

Despite the fact that the study's findings cannot be generalised, the authors believe that the article offers good material for thought for supervisors, doctoral students and developers of doctoral study. Authors find that the results provide the basis for planning next studies, which could focus on researching the incentives, frequency and content of supervisees' and supervisors' supervisory meetings from the perspective of both sides. For doctoral students, the article could offer encouragement for advancing in postgraduate studies through the motto from the article's title „Through hardships to the stars".

Keywords: postgraduate study, aspirant, doctoral student, postgraduate supervision, interview 